\title{
Food security in the Baltic Republics
}

\author{
Joceline Pomerleau ${ }^{1}$, Martin McKee ${ }^{1, *}$, Aileen Robertson ${ }^{2}$, Sirje Vaask ${ }^{3}$, Iveta Pudule ${ }^{4}$, \\ Daiga Grinberga ${ }^{4}$, Algis Abaraviciuss ${ }^{5}$ and Roma Bartkeviciute 6 \\ ${ }^{1}$ European Centre on Health of Societies in Transition, London School of Hygiene and Tropical Medicine, Keppel \\ Street, London WC1E 7HT, UK: ${ }^{2}$ WHO Regional Office for Europe, Scherfigsvej 8, DK-2 100 Copenhagen $\varnothing$, \\ Denmark: ${ }^{3}$ Public Health Department, Ministry of Social Affairs, Gonsiori str. 29, EE-0100 Tallinn, Estonia: ${ }^{4}$ Health \\ Education Division, Health Promotion Centre, Skolas 3, LV-1010 Riga, Latvia: ${ }^{5}$ Faculty of Medicine, Department of \\ Physiology and Biochemistry, Vilnius University, Ciurlionio str. 21/27, 2009 Vilnius, Lithuania: ${ }^{6}$ National Nutrition \\ Centre, Kalvariju 153, 2042 Vilnius, Lithuania
}

Submitted 16 May 2001: Accepted 18 0ctober 2001

\begin{abstract}
Objectives: Food insecurity has become an important issue in many countries of the former Soviet Union following the transition to a market economy. This study examined three aspects of food security in the Baltic Republics: reasons for choosing foods; level of dependence on home-grown or raised foods; and use of home-grown vegetables.

Design: Cross-sectional surveys.

Setting: Data from surveys conducted in Estonia, Latvia and Lithuania in the summer of 1997 were used to describe the three aspects of food security and their socioeconomic correlates (using descriptive statistics and logistic regression).

Subjects: Representative samples of adults were selected in each country (Estonia, $n=2018$; Latvia, $n=2308$; Lithuania, $n=2153$ ).

Results: Cost was the most commonly reported reason for choosing foods, particularly in Lithuania (67\%) and Latvia (60\%) (Estonia 41\%), and especially among people with lower income levels. In each country, large proportions of respondents depended partially or entirely on home-grown or raised foods (Latvia $47 \%$, Lithuania 42\%, Estonia 32\%) or used home-grown vegetables frequently (Lithuania 66\%, Latvia 53\%, Estonia 29\%); this was particularly the case in rural areas.

Conclusions: The issue of food security needs to be examined further in the Baltic Republics and other transitional economies as increased access to safe, healthy foods for all could help improve dietary intake and reduce the high mortality from noncommunicable diseases. Access to affordable, high-quality fresh foods by different social groups should be monitored and the potential contribution of home-grown and raised foods to reduce food poverty should be explored further.
\end{abstract}

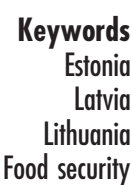

Keywords

Estonia

Latvia

Food security
The concept of food security implies that all people have access at all times to sufficient affordable food, in terms of quantity, quality and diversity, for an active healthy life ${ }^{1}$. Unequal access to safe and healthy food is emerging as a major issue in some parts of Eastern Europe and the former Soviet Union, reflecting the uncertain conditions arising from the very rapid economic and social changes encountered $^{2,3}$. In 1999, the Food and Agriculture Organization estimated that 26 million people living in these regions suffered from chronic food insecurity, defined as having an intake that does not provide enough energy to meet basic energy requirements ${ }^{4}$.

In the Baltic countries, the economic changes of the transition to market economy have reduced the availability of certain foods for some population subgroups, particularly the poor. A reduction in subsidies increased the price of goods, real wages fell by about 52\% between 1989 and 1995 , unemployment increased by approximately six percentage points between 1991 (1992 in Latvia) and 1995, and the proportion of the household budget being spent on foods an index often used as a measure of poverty - increased by $12 \%$ after the economic transition ${ }^{5,6}$.

In 1996, the World Health Organization (WHO) facilitated the Baltic Project, funded by the Luxembourg Government, to support Estonia, Latvia and Lithuania to carry out national surveys of food patterns and lifestyle behaviours, including some aspects of food security. In this paper, we explore these aspects, i.e. the main reasons reported for choosing foods, the level of dependence on home-grown or raised foods, and the frequency of use of home-grown vegetables. In each case the impact on different socio-economic groups is explored. 


\section{Methods}

Details of methods used in the Baltic Nutrition Surveys have been described previously ${ }^{7}$. The surveys sought to include representative samples of the national population aged between 19 and 64 years (19-65 years in Lithuania) using national population registers as the sampling frames. A simple random sample of 3000 people was drawn from each country's population register. In Estonia, sampling was stratified by age group. In Latvia, it was stratified by region, with further stratification by age group in Riga. In Latvia and Lithuania, substitution was not permitted but the interviewers returned to an address on multiple occasions if they were unable to find the person. In Estonia, substitution was allowed if the response rate in the county in question was less than 60\%; substitutes were selected on the basis of place of residence (usually neighbours, especially in the countryside). Overall, less than $5 \%$ of individuals, in seven Estonian counties, were substituted. Response rates were 67.3\% in Estonia, $77.7 \%$ in Latvia, and $72.7 \%$ in Lithuania. Interviewers were mainly assistants working in hygiene stations, who underwent an initial one-day training session.

Survey interviews were conducted during the summer of 1997 in the respondents' homes in the national language or in Russian. Interviews included a standardised questionnaire, a 24-hour recall of dietary intake, and the measurement of height and weight. The intervieweradministered questionnaire covered socio-economic characteristics, health behaviours, and dietary habits and beliefs.

Most of the variables analysed are self-explanatory. The income variable relates to family income. It was divided into four categories according to values that were countryspecific. In Estonia, where the government had specified a minimum standard of living, which was set at \$75 in 1997 , this was used to define the lowest category, considered to be severe poverty. In Latvia and Lithuania, where official figures did not exist, $\$ 50$ and $\$ 47.5$ were used as the minimum levels, after discussion with national informants who had compared prices in the three countries. The cutoff points for the other categories were set at two and three times this value (e.g. $<\$ 50, \$ 50-99, \$ 100-149, \$ 150+$ in Latvia) except in Lithuania, where the income distribution was rather narrower and the cut-off points were set at $160 \%$ and $200 \%$ of the poverty line, so as to create similar sized groups to those in the other countries.

Data were analysed using the statistical package STATA version 6.0 (College Station, TX). All individuals with missing information on age were excluded from the analyses $(n=18)$, as were pregnant women $(n=35$; in Estonia, pregnant women were not included in the study). In Lithuania, three respondents were over 65 years of age but were kept in the analyses. Between-country differences in the reasons for choosing foods, the level of dependence on own-grown or raised foods, and the frequency of use of home-grown vegetables were explored using chi-square tests, stratifying by age and sex. The odds of having selected 'cost' as the main reason for choosing foods rather than taste, preference, presumed health benefits or adherence to a special diet were calculated using multiple regression analyses according to a range of socio-economic variables; all variables were included simultaneously in the regression model. Similarly, socio-economic correlates of the likelihood of being partially or entirely dependent on own-grown/raised foods and of frequent use of home-grown vegetables were investigated. Statistical significance was taken as $P<0.05$.

\section{Results}

Table 1 shows socio-economic characteristics of the study sample by country and gender. Significant differences among countries were observed for the distribution by age, nationality, education level, work activity and income, but no difference existed for the area of residence - almost two-thirds of the respondents lived in urban areas. Overall, respondents from Estonia were younger, and those from Latvia were older, than respondents from Lithuania. The sample from Lithuania was the most homogeneous in terms of nationality, with $85 \%$ of the respondents being of Lithuanian nationality, $8 \%$ of Russian nationality and $7 \%$ of other nationalities. In comparison, almost one in four respondents from Estonia and one in three respondents from Latvia were of Russian nationality. In each case these reflected census data.

The proportion of participants who went only to primary school was slightly higher in Latvia and Lithuania than in Estonia. The proportion of respondents with more than secondary education was lowest in Estonia and highest in Lithuania. The majority of the respondents were currently employed (between 55\% and 65\% among countries). The overall country-specific unemployment rate varied between 11\% (Estonia) and 18\% (Lithuania), but reached $24 \%$ in Lithuanian men. One-third of the respondents were considered to be living in severe poverty (lowest income group), with variations from $28 \%$ in Estonia up to 38\% in Lithuania.

\section{Reasons for choosing foods}

In each country, cost was the most commonly reported reason for choosing foods (Table 2). However, the proportion of respondents selecting foods based on their cost was considerably higher in Lithuania (67\%) and Latvia (60\%) than in Estonia (41\%). In contrast, Estonians were more likely than their Latvian and Lithuanian counterparts to choose foods because of their taste (28\% vs. 19\% and $16 \%$, respectively) or because of family preferences $(19 \%$ vs. $14 \%$ and 6\%). Prevention of diseases and the need to follow a special diet were reported less frequently by participants as the main reason for choosing foods. Older respondents were generally more likely than younger 
Table 1 Selected characteristics of the respondents by country and sex

\begin{tabular}{|c|c|c|c|c|c|c|}
\hline \multirow[b]{2}{*}{ Characteristic } & \multicolumn{3}{|c|}{ Men } & \multicolumn{3}{|c|}{ Women } \\
\hline & Estonia & Latvia & Lithuania & Estonia & Latvia & Lithuania \\
\hline \multicolumn{7}{|l|}{ Age $(\%)^{*}$} \\
\hline $19-34$ years & 44.0 & 31.5 & 35.5 & 41.1 & 27.6 & 30.8 \\
\hline $35-49$ years & 35.5 & 34.9 & 36.6 & 33.7 & 32.0 & 35.3 \\
\hline $50+$ years & 20.5 & 33.6 & 28.0 & 25.2 & 40.4 & 34.0 \\
\hline Mean age (SD + ) & $38(12)$ & $43(13)$ & $41(13)$ & $39(13)$ & $44(13)$ & $43(13)$ \\
\hline Base & 902 & 1070 & 987 & 1116 & 1238 & 1166 \\
\hline \multicolumn{7}{|l|}{ Nationality $(\%)^{*}$} \\
\hline Estonian/Latvian/Lithuanian & 71.6 & 55.6 & 83.1 & 68.0 & 54.0 & 86.1 \\
\hline Russian & 22.5 & 33.6 & 9.3 & 25.2 & 35.8 & 7.7 \\
\hline Other & 5.9 & 10.8 & 7.6 & 6.8 & 10.2 & 6.3 \\
\hline Base & 902 & 1070 & 987 & 1116 & 1237 & 1161 \\
\hline \multicolumn{7}{|l|}{ Area of residence (\%) } \\
\hline Urban & 60.8 & 65.9 & 65.8 & 70.4 & 67.2 & 67.7 \\
\hline Rural & 39.3 & 34.1 & 34.3 & 29.6 & 32.8 & 32.3 \\
\hline Base & 902 & 1070 & 987 & 1116 & 1238 & 1166 \\
\hline \multicolumn{7}{|l|}{ Education level (\%)* } \\
\hline Primary & 15.1 & 21.0 & 22.4 & 10.7 & 18.0 & 18.6 \\
\hline Secondary & 47.7 & 31.3 & 26.2 & 44.4 & 33.3 & 24.9 \\
\hline Secondary special/university & 37.3 & 47.7 & 51.4 & 45.0 & 48.7 & 56.6 \\
\hline Base & 902 & 1047 & 982 & 1116 & 1211 & 1159 \\
\hline \multicolumn{7}{|l|}{ Work activity $(\%)^{*}$} \\
\hline Working & 71.5 & 61.7 & 64.7 & 59.5 & 48.7 & 53.2 \\
\hline Unemployed & 14.1 & 19.6 & 23.8 & 8.6 & 14.3 & 12.5 \\
\hline Pensioner/disabled & 7.4 & 12.5 & 9.6 & 14.9 & 26.0 & 19.1 \\
\hline Housewife & 1.0 & 3.3 & 0.4 & 8.5 & 8.3 & 13.4 \\
\hline Student & 6.0 & 3.0 & 1.4 & 8.5 & 2.8 & 1.9 \\
\hline Base & 902 & 1069 & 987 & 1116 & 1237 & 1164 \\
\hline \multicolumn{7}{|l|}{ Income (\%)* } \\
\hline Level 1 - low & 24.7 & 34.9 & 40.3 & 30.9 & 37.8 & 36.4 \\
\hline Level 2 & 33.5 & 44.2 & 27.0 & 40.4 & 48.1 & 30.7 \\
\hline Level 3 & 28.2 & 12.8 & 11.0 & 22.7 & 9.5 & 11.9 \\
\hline Level 4 - high & 13.6 & 8.0 & 21.7 & 6.0 & 4.7 & 21.0 \\
\hline Base & 902 & 1020 & 911 & 1116 & 1204 & 1118 \\
\hline
\end{tabular}

* Significant variations $(P<0.001)$ among countries in men and in women, using chi-square tests. †SD - standard deviation.

respondents to report choosing foods because of their cost, because they wanted to prevent diseases, or because of a special diet. Older individuals were also less likely to choose foods according to taste. Taste was reported more frequently by men than by women as the main reason to choose foods, while the reverse was true for the prevention of diseases and for special diets. In Estonia and Latvia, women were more likely than men to select cost as their main reason for choosing foods.

Table 3 gives the odds of having selected cost as the main reason for choosing foods by the levels of different socio-economic characteristics. After adjusting for all other variables (taken simultaneously in the regression model), income was the most consistent predictor of this likelihood, with the poor of either gender and in all three countries much more likely to cite cost as the main factor $(P<0.001)$. In Estonia and Latvia, a direct relationship between age and the likelihood of selecting foods mainly because of their cost was also noted $(P<0.001)$ : individuals over 50 years of age were approximately twice as likely as those between 18 and 34 years to mention cost as their main reason for choosing foods (with odds ratios (ORs) varying between 1.88 and
2.60). Russian men and women showed a generally higher likelihood of choosing foods because of their cost, after adjustment for other variables, but significance was reached only among Latvians $(\mathrm{OR}=3.05$ in men and 1.48 in women $)$ and Estonian females $(O R=2.06)$. Finally, even after adjusting for income and for the other variables, a lower level of education increased the odds of selecting foods because of their costs in three gender/country groups: in Lithuanian men $(P<0.001)$, Latvian women $(P<0.01)$ and Estonian women $(P<0.05)$.

\section{Dependence on bome-grown or raised foods}

The level of dependence on home-grown or raised foods varied greatly among countries (Table 4). In Estonia, more than half the respondents did not depend at all on homegrown/raised foods compared with $29 \%$ of Latvians and $38 \%$ of Lithuanians. In comparison, more than twice as many Lithuanians (29\%) as Estonians (13\%) and Latvians (14\%) reported depending entirely on home-grown or raised foods. In each country, at least about a third of the respondents - up to almost half of the Latvian respondents - depended partially or entirely on homegrown foods (47\% in Latvia, $42 \%$ in Lithuania and 32\% in 
Estonia). No marked differences were observed between men and women.

Results from multivariate regression analyses (Table 5) suggested, intuitively, that the area of residence was a strong predictor of the level of dependence on homegrown or raised foods, all other factors being kept equal. The association was strongest in Lithuania, where the respondents from rural regions were approximately 11 times as likely as their counterparts living in urban areas to be partially or entirely dependent on home-grown or raised foods. The association was intermediate in Latvia (OR between 7.46 and 8.45) and lowest in Estonia (OR between 2.80 and 4.28). Age, nationality and income were also correlated with the level of dependence on homegrown or raised foods after adjusting for all other factors. The odds of a higher level of dependence increased with age in Latvian men $(P<0.01)$ and in Estonian and Latvian women $(P<0.05)$, while it decreased with income level in men from each country $(P<0.01)$ and in Latvian women $(P<0.05)$. Finally, in Estonia and Latvia, Russian respondents were approximately 50\% less likely than their Estonian or Latvian counterparts to depend at least partially on home-grown or raised foods; this was also the case for respondents of other nationalities living in Estonia.

\section{Use of bome-grown vegetables}

The main findings for the reported use of home-grown vegetables paralleled those for the level of dependence on home-grown or raised foods. Respondents from Estonia used home-grown vegetables less frequently than other respondents: more than $40 \%$ never used them compared with only $27 \%$ of Latvians and $17 \%$ of Lithuanians (Table 4 ). The proportion of respondents who often used homegrown vegetables was particularly high in Lithuania: twothirds of the respondents from this country frequently used such vegetables compared with $53 \%$ of the Latvians but only 29\% of the Estonians.

Living in a rural area was a strong predictor of the frequent use of home-grown vegetables (Table 6). As with dependence on home-grown and raised foods, the association was strongest in Lithuania $(\mathrm{OR}=9.23$ in men and 21.39 in women) and lowest in Estonia (OR $=2.90$ in men and 3.79 in women). There was a positive association between the frequent use of home-grown vegetables and age in Estonian males and females $(P<0.05)$ and in Latvian males $(P<0.005)$. However, the odds of often using home-grown vegetables decreased with income in Latvia. Finally, in each country, Russian respondents were significantly less likely (between 36 and 64\% less) to use home-grown vegetables frequently compared with their native counterparts.

\section{Discussion}

These surveys show that cost was the most important 
Table 3 Likelihood of selecting cost as the main reason for choosing foods

\begin{tabular}{|c|c|c|c|c|c|c|c|c|c|c|c|c|}
\hline \multirow[b]{3}{*}{ Group } & \multicolumn{6}{|c|}{ Men } & \multicolumn{6}{|c|}{ Women } \\
\hline & \multicolumn{2}{|c|}{ Estonia } & \multicolumn{2}{|r|}{ Latvia } & \multicolumn{2}{|c|}{ Lithuania } & \multicolumn{2}{|c|}{ Estonia } & \multicolumn{2}{|r|}{ Latvia } & \multicolumn{2}{|c|}{ Lithuania } \\
\hline & $\mathrm{OR}^{*}$ & $95 \% \mathrm{Cl}^{*}$ & OR & $95 \% \mathrm{Cl}$ & OR & $95 \% \mathrm{Cl}$ & OR & $95 \% \mathrm{Cl}$ & OR & $95 \% \mathrm{Cl}$ & OR & $95 \% \mathrm{Cl}$ \\
\hline \multicolumn{13}{|l|}{ Age group } \\
\hline $18-34$ years & 1.00 & & 1.00 & & 1.00 & & 1.00 & & 1.00 & & 1.00 & \\
\hline $35-49$ years & 2.47 & $1.70 ; 3.60$ & 1.48 & $1.04 ; 2.10$ & 1.11 & $0.78 ; 1.56$ & 1.83 & $1.33 ; 2.51$ & 1.15 & $0.83 ; 1.60$ & 1.03 & $0.75 ; 1.43$ \\
\hline $50+$ years & 2.17 & $1.39 ; 3.39$ & 2.60 & $1.79 ; 3.77$ & 0.95 & $0.64 ; 1.43$ & 1.99 & $1.40 ; 2.83$ & 1.88 & $1.35 ; 2.62$ & 0.93 & $0.65 ; 1.33$ \\
\hline \multicolumn{13}{|c|}{ ( } \\
\hline Estonian/Latvian/Lithuanian & 1.00 & & 1.00 & & 1.00 & & 1.00 & & 1.00 & & 1.00 & \\
\hline Russian & 1.36 & $0.91 ; 2.03$ & 3.05 & $2.14 ; 4.34$ & 1.13 & $0.67 ; 1.92$ & 2.06 & $1.49 ; 2.84$ & 1.48 & $1.10 ; 1.99$ & 1.30 & $0.77 ; 2.19$ \\
\hline Other & 0.95 & $0.46 ; 1.95$ & 1.32 & $0.81 ; 2.14$ & 1.26 & $0.70 ; 2.27$ & 1.32 & $0.76 ; 2.29$ & 0.76 & $0.49 ; 1.18$ & 1.71 & $0.93 ; 3.13$ \\
\hline \multicolumn{13}{|c|}{ (1) } \\
\hline Urban & 1.00 & & 1.00 & & 1.00 & & 1.00 & & 1.00 & & 1.00 & \\
\hline Rural & 0.97 & $0.69 ; 1.37$ & 1.03 & $0.73 ; 1.43$ & 0.77 & $0.55 ; 1.08$ & 1.43 & $1.06 ; 1.92$ & 0.79 & $0.58 ; 1.06$ & 0.76 & $0.57 ; 1.03$ \\
\hline \multicolumn{13}{|c|}{ } \\
\hline Primary & 1.00 & & 1.00 & & 1.00 & & 1.00 & & 1.00 & & 1.00 & \\
\hline Secondary & 0.63 & $0.38 ; 1.05$ & 1.31 & $0.86 ; 2.00$ & 0.62 & $0.38 ; 1.02$ & 0.69 & $0.42 ; 1.14$ & 0.73 & $0.48 ; 1.12$ & 0.89 & $0.56 ; 1.41$ \\
\hline Secondary special/university & 0.68 & $0.40 ; 1.16$ & 0.80 & $0.54 ; 1.20$ & 0.45 & $0.28 ; 0.70$ & 0.58 & $0.35 ; 0.97$ & 0.59 & $0.39 ; 0.89$ & 0.82 & $0.54 ; 1.25$ \\
\hline \multicolumn{13}{|c|}{ Income level } \\
\hline Level 1 - low & 1.00 & & 1.00 & & 1.00 & & 1.00 & & 1.00 & & 1.00 & \\
\hline Level 2 & 0.25 & $0.17 ; 0.38$ & 0.46 & $0.33 ; 0.64$ & 0.62 & $0.42 ; 0.91$ & 0.53 & $0.39 ; 0.71$ & 0.48 & $0.35 ; 0.65$ & 0.72 & $0.51 ; 1.01$ \\
\hline Level 3 & 0.06 & $0.04 ; 0.10$ & 0.18 & $0.11 ; 0.29$ & 0.55 & $0.33 ; 0.91$ & 0.14 & $0.09 ; 0.21$ & 0.13 & $0.08 ; 0.21$ & 0.59 & $0.37 ; 0.92$ \\
\hline Level 4 - high & 0.01 & $0.00 ; 0.03$ & 0.02 & $0.01 ; 0.05$ & 0.24 & $0.16 ; 0.36$ & 0.03 & $0.01 ; 0.11$ & 0.08 & $0.04 ; 0.17$ & 0.24 & $0.17 ; 0.35$ \\
\hline
\end{tabular}

* OR - odds ratio; $\mathrm{Cl}$ - confidence interval.

consideration when choosing foods in the Baltic countries. This was particularly the case in Lithuania (67\%) and Latvia (60\%), where levels of unemployment and poverty were high. In Lithuania, almost one in four male participants were unemployed at the time of the survey and 38\% were considered to live in severe poverty. In Latvia, one in six respondents was unemployed and 36\% lived in severe poverty. In comparison, only $41 \%$ of Estonians reported selecting their foods mainly because of their cost; in that country $11 \%$ of the respondents were unemployed and $28 \%$ reported living in severe poverty. As expected, a low income level was the strongest and most consistent predictor of choosing foods primarily based on their cost in each country. A caveat is, however, required as formal income fails to capture household transactions that do not involve cash transfers. Unfortunately, alternative measures such as inventories of household assets are extremely difficult to measure in surveys.

We also observed that, even after adjusting for income, educational achievement was also related to the reasons for choosing foods in some population subgroups. Lithuanian men and Estonian and Latvian women with higher education were significantly less likely to select cost as the main reason compared with their counterparts with primary education.

A limited budget is often the principal barrier to healthier and safer food choices. Food poverty - defined as having inadequate access to a healthy $\operatorname{diet}^{8}-$ is usually accompanied by the intake of inexpensive sources of energy such as high-fat products or sugars and preserves that are relatively poor in micronutrients, and by a low intake of fruits and vegetables. In Lithuania, it was reported that the recent increases in food prices have caused poorer people to consume cheaper, less nutrientdense foods that are more likely to be contaminated and thus less healthy and safe? . This is especially worrying as it builds on traditional diets that are high in fat and poor in vegetables and fruits ${ }^{10}$, a pattern which strongly disagrees with current international dietary guidelines $9,11,12$.

The level of dependence on home-grown or raised foods in the Baltic States, and the frequency of use of home-grown vegetables, paralleled the findings described above. Estonians, who were the least likely to choose their foods primarily according to cost, were also the least likely to depend on home-grown or raised foods and to use home-grown vegetables. Conversely, Lithuanians were the most likely to depend entirely on these foods and to use home-grown vegetables frequently. In each country, however, at least about a third of the respondents - up to almost half of the Latvian respondents - depended partially or entirely on home-grown or raised foods. This provides an important source of healthy foods for many people in the three countries studied and is of particular benefit to the poor. It is believed that home production is one reason why families living in countries undergoing economic transition are not suffering from protein-energy malnutrition $^{13,14}$.

As expected, individuals living in a rural area reported being more dependent on home-grown or raised foods than their urban counterparts, and they used home-grown vegetables more frequently. This clearly reflects increased access to gardens or farming land. Lack of access to land is thus a key determinant of food poverty. During periods of economic stress, people living in rural areas can more 
Table 4 Level of dependence on home-grown or raised foods and frequency of use of home-grown vegetables by country, sex and age group

\begin{tabular}{|c|c|c|c|c|c|c|c|c|c|c|c|c|c|c|c|c|}
\hline \multirow[b]{3}{*}{ Group } & \multicolumn{5}{|c|}{ Estonia } & \multicolumn{5}{|c|}{ Latvia } & \multicolumn{5}{|c|}{ Lithuania } & \multirow[b]{3}{*}{$P$-value } \\
\hline & \multicolumn{15}{|c|}{ Level of dependence on home-grown or raised foods } & \\
\hline & $n$ & $\begin{array}{c}\text { Not at all } \\
(\%)\end{array}$ & $\begin{array}{c}\text { A little } \\
(\%)\end{array}$ & $\begin{array}{c}\text { Partially } \\
(\%)\end{array}$ & $\begin{array}{c}\text { Entirely } \\
(\%)\end{array}$ & $n$ & $\begin{array}{c}\text { Not at all } \\
(\%)\end{array}$ & $\begin{array}{c}\text { A little } \\
(\%)\end{array}$ & $\begin{array}{c}\text { Partially } \\
(\%)\end{array}$ & $\begin{array}{c}\text { Entirely } \\
(\%)\end{array}$ & $n$ & $\begin{array}{c}\text { Not at all } \\
(\%)\end{array}$ & $\begin{array}{c}\text { A little } \\
(\%)\end{array}$ & $\begin{array}{c}\text { Partially } \\
(\%)\end{array}$ & $\begin{array}{c}\text { Entirely } \\
(\%)\end{array}$ & \\
\hline All men & 902 & 51.7 & 16.2 & 19.0 & 13.2 & 1069 & 29.0 & 23.5 & 33.2 & 14.3 & 985 & 36.9 & 19.9 & 15.3 & 27.9 & $<0.001$ \\
\hline $18-34$ years & 397 & 55.7 & 14.6 & 18.1 & 11.6 & 337 & 34.1 & 22.3 & 30.3 & 13.4 & 349 & 33.0 & 22.6 & 17.5 & 26.9 & $<0.001$ \\
\hline $35-49$ years & 320 & 50.9 & 17.5 & 16.9 & 14.7 & 372 & 29.0 & 25.3 & 31.7 & 14.0 & 361 & 37.1 & 19.9 & 15.2 & 27.7 & $<0.001$ \\
\hline $50+$ years & 185 & 44.3 & 17.3 & 24.3 & 14.1 & 360 & 24.2 & 22.8 & 37.5 & 15.6 & 275 & 41.5 & 16.4 & 12.7 & 29.5 & $<0.001$ \\
\hline All women & 1116 & 54.8 & 12.8 & 19.7 & 12.6 & 1234 & 28.9 & 24.5 & 32.2 & 14.4 & 1166 & 39.1 & 19.0 & 11.7 & 30.2 & $<0.001$ \\
\hline $18-34$ years & 459 & 60.1 & 13.1 & 17.9 & 8.9 & 342 & 29.2 & 24.9 & 31.3 & 14.6 & 359 & 35.7 & 23.1 & 13.9 & 27.3 & $<0.001$ \\
\hline $35-49$ years & 376 & 52.1 & 12.0 & 23.4 & 12.5 & 395 & 31.7 & 23.0 & 32.4 & 12.9 & 411 & 42.6 & 19.5 & 12.2 & 25.8 & $<0.001$ \\
\hline \multirow[t]{3}{*}{$50+$ years } & 281 & 49.8 & 13.5 & 17.8 & 18.9 & 497 & 26.6 & 25.4 & 32.6 & 15.5 & 396 & 38.6 & 14.9 & 9.1 & 37.4 & $<0.001$ \\
\hline & \multicolumn{15}{|c|}{ Use of home-grown vegetables } & \\
\hline & $n$ & $\begin{array}{l}\text { No } \\
(\%)\end{array}$ & $\begin{array}{c}\text { Sometimes } \\
(\%)\end{array}$ & $\begin{array}{l}\text { Often } \\
(\%)\end{array}$ & & $n$ & $\begin{array}{l}\text { No } \\
(\%)\end{array}$ & $\begin{array}{c}\text { Sometimes } \\
(\%)\end{array}$ & $\begin{array}{l}\text { Often } \\
(\%)\end{array}$ & & $n$ & $\begin{array}{l}\text { No } \\
(\%)\end{array}$ & $\begin{array}{c}\text { Sometimes } \\
(\%)\end{array}$ & $\begin{array}{c}\text { Often } \\
(\%)\end{array}$ & & \\
\hline All men & 902 & 43.0 & 28.5 & 28.5 & & 1060 & 27.7 & 20.2 & 52.1 & & 987 & 15.4 & 16.7 & 67.9 & & $<0.001$ \\
\hline $18-34$ years & 397 & 45.1 & 29.5 & 25.4 & & 335 & 32.2 & 20.0 & 47.8 & & 350 & 15.4 & 18.6 & 66.0 & & $<0.001$ \\
\hline $35-49$ years & 320 & 44.4 & 26.6 & 29.1 & & 371 & 27.2 & 21.8 & 50.9 & & 361 & 12.7 & 17.7 & 69.5 & & $<0.001$ \\
\hline $50+$ years & 185 & 36.2 & 29.7 & 34.1 & & 354 & 24.0 & 18.6 & 57.3 & & 276 & 18.8 & 13.0 & 68.1 & & $<0.001$ \\
\hline All women & 1116 & 41.1 & 29.0 & 29.8 & & 1228 & 27.1 & 19.4 & 53.5 & & 1164 & 18.0 & 16.6 & 65.5 & & $<0.001$ \\
\hline $18-34$ years & 459 & 42.1 & 32.9 & 25.1 & & 342 & 29.2 & 16.7 & 54.1 & & 359 & 16.4 & 20.3 & 63.2 & & $<0.001$ \\
\hline $35-49$ years & 376 & 40.4 & 27.7 & 31.9 & & 390 & 29.0 & 18.7 & 52.3 & & 409 & 20.5 & 15.4 & 64.1 & & $<0.001$ \\
\hline $50+$ years & 281 & 40.6 & 24.6 & 34.9 & & 496 & 24.2 & 21.8 & 54.0 & & 396 & 16.7 & 14.4 & 68.9 & & $<0.001$ \\
\hline
\end{tabular}

* $P$-value for variations among countries in the use of home-grown vegetables, using chi-square tests. 
Table 5 Likelihood of depending partially or entirely on home-grown or raised foods

\begin{tabular}{|c|c|c|c|c|c|c|c|c|c|c|c|c|}
\hline \multirow[b]{3}{*}{ Group } & \multicolumn{6}{|c|}{ Men } & \multicolumn{6}{|c|}{ Women } \\
\hline & \multicolumn{2}{|c|}{ Estonia } & \multicolumn{2}{|r|}{ Latvia } & \multicolumn{2}{|c|}{ Lithuania } & \multicolumn{2}{|c|}{ Estonia } & \multicolumn{2}{|r|}{ Latvia } & \multicolumn{2}{|c|}{ Lithuania } \\
\hline & $\mathrm{OR}^{*}$ & $95 \% \mathrm{Cl}^{*}$ & OR & $95 \% \mathrm{Cl}$ & OR & $95 \% \mathrm{Cl}$ & OR & $95 \% \mathrm{Cl}$ & OR & $95 \% \mathrm{Cl}$ & OR & $95 \% \mathrm{Cl}$ \\
\hline \multicolumn{13}{|l|}{ Age group } \\
\hline $18-34$ years & 1.00 & & 1.00 & & 1.00 & & 1.00 & & 1.00 & & 1.00 & \\
\hline $35-49$ years & 1.10 & $0.78 ; 1.54$ & 1.14 & $0.79 ; 1.64$ & 1.01 & $0.70 ; 1.46$ & 1.49 & $1.08 ; 2.05$ & 1.20 & $0.84 ; 1.70$ & 0.90 & $0.64 ; 1.29$ \\
\hline $50+$ years & 1.37 & $0.92 ; 2.05$ & 1.70 & $1.17 ; 2.47$ & 0.91 & $0.59 ; 1.40$ & 1.41 & $0.98 ; 2.04$ & 1.42 & $1.01 ; 2.01$ & 0.84 & $0.56 ; 1.24$ \\
\hline \multicolumn{13}{|c|}{ Nationality } \\
\hline Estonian/Latvian/Lithuanian & 1.00 & & 1.00 & & 1.00 & & 1.00 & & 1.00 & & 1.00 & \\
\hline Russian & 0.54 & $0.37 ; 0.80$ & 0.48 & $0.35 ; 0.67$ & 0.62 & $0.35 ; 1.09$ & 0.45 & $0.31 ; 0.64$ & 0.49 & $0.37 ; 0.66$ & 0.68 & $0.38 ; 1.21$ \\
\hline Other & 0.46 & $0.23 ; 0.92$ & 0.64 & $0.40 ; 1.02$ & 1.47 & $0.83 ; 2.60$ & 0.41 & $0.22 ; 0.75$ & 0.68 & $0.44 ; 1.06$ & 1.66 & $0.95 ; 2.93$ \\
\hline \multicolumn{13}{|l|}{ Area of residence } \\
\hline Urban & 1.00 & & 1.00 & & 1.00 & & 1.00 & & 1.00 & & 1.00 & \\
\hline Rural & 2.80 & $2.08 ; 3.78$ & 7.46 & $5.29 ; 10.51$ & 10.15 & $7.18 ; 14.37$ & 4.28 & $3.22 ; 5.70$ & 8.45 & $6.15 ; 11.62$ & 11.68 & $8.45 ; 16.16$ \\
\hline \multicolumn{13}{|c|}{ - } \\
\hline Primary & 1.00 & & 1.00 & & 1.00 & & 1.00 & & 1.00 & & 1.00 & \\
\hline Secondary & 1.17 & $0.73 ; 1.87$ & 1.12 & $0.74 ; 1.72$ & 0.73 & $0.45 ; 1.19$ & 0.84 & $0.50 ; 1.38$ & 0.98 & $0.65 ; 1.46$ & 0.58 & $0.36 ; 0.95$ \\
\hline Secondary special/university & 1.28 & $0.79 ; 2.07$ & 1.32 & $0.88 ; 2.00$ & 1.12 & $0.72 ; 1.75$ & 0.77 & $0.46 ; 1.30$ & 1.38 & $0.93 ; 2.04$ & 0.62 & $0.40 ; 0.96$ \\
\hline \multicolumn{13}{|c|}{ Income level } \\
\hline Level 1 - low & 1.00 & & 1.00 & & 1.00 & & 1.00 & & 1.00 & & 1.00 & \\
\hline Level 2 & 0.61 & $0.41 ; 0.90$ & 0.81 & $0.58 ; 1.14$ & 0.76 & $0.52 ; 1.12$ & 1.10 & $0.79 ; 1.53$ & 0.71 & $0.53 ; 0.96$ & 0.80 & $0.56 ; 1.14$ \\
\hline Level 3 & 0.57 & $0.37 ; 0.86$ & 0.80 & $0.49 ; 1.30$ & 0.68 & $0.40 ; 1.16$ & 0.69 & $0.46 ; 1.05$ & 0.65 & $0.40 ; 1.06$ & 1.07 & $0.67 ; 1.73$ \\
\hline Level 4 - high & 0.50 & $0.29 ; 0.85$ & 0.36 & $0.19 ; 0.68$ & 0.53 & $0.34 ; 0.83$ & 1.22 & $0.66 ; 2.25$ & 0.64 & $0.33 ; 1.25$ & 0.71 & $0.47 ; 1.07$ \\
\hline
\end{tabular}

*OR - odds ratio; $\mathrm{Cl}$ - confidence interval.

easily maintain a balanced diet than those living in urban areas because of access to land on which they can produce foods ${ }^{15}$. This is likely to have been a contributory factor in the decline in health seen in industralising and urbanising countries in the nineteenth century ${ }^{16}$. However, the availability of home-grown or raised foods does not necessarily translate into food security in relation to important micronutrients. The Baltic Nutrition Surveys indicated that the median daily intake of vegetables and fruit (excluding potatoes) in Latvia ${ }^{10}$ is $200 \mathrm{~g}$, less than the WHO recommendation of at least $400 \mathrm{~g} \mathrm{day}^{-1}$. In the other Baltic countries the situation is similar with median daily intakes between approximately 250 and $300 \mathrm{~g}$, although median consumption of fruit and vegetables in this survey

Table 6 Likelihood of using home-grown vegetables frequently

\begin{tabular}{|c|c|c|c|c|c|c|c|c|c|c|c|c|}
\hline \multirow[b]{3}{*}{ Group } & \multicolumn{6}{|c|}{ Men } & \multicolumn{6}{|c|}{ Women } \\
\hline & \multicolumn{2}{|c|}{ Estonia } & \multicolumn{2}{|r|}{ Latvia } & \multicolumn{2}{|c|}{ Lithuania } & \multicolumn{2}{|c|}{ Estonia } & \multicolumn{2}{|r|}{ Latvia } & \multicolumn{2}{|r|}{ Lithuania } \\
\hline & $\mathrm{OR}^{*}$ & $95 \% \mathrm{Cl}^{*}$ & OR & $95 \% \mathrm{Cl}$ & OR & $95 \% \mathrm{Cl}$ & OR & $95 \% \mathrm{Cl}$ & OR & $95 \% \mathrm{Cl}$ & OR & $95 \% \mathrm{Cl}$ \\
\hline \multicolumn{13}{|l|}{ Age group } \\
\hline $18-34$ years & 1.00 & & 1.00 & & 1.00 & & 1.00 & & 1.00 & & 1.00 & \\
\hline $35-49$ years & 1.27 & $0.89 ; 1.81$ & 1.26 & $0.88 ; 1.80$ & 1.38 & $0.96 ; 1.98$ & 1.31 & $0.95 ; 1.81$ & 1.05 & $0.74 ; 1.50$ & 1.14 & $40.81 ; 1.60$ \\
\hline $50+$ years & 1.50 & $0.99 ; 2.27$ & 1.74 & $1.20 ; 2.53$ & 1.08 & $0.72 ; 1.65$ & 1.42 & $0.99 ; 2.05$ & 1.22 & $0.87 ; 1.72$ & 1.13 & $30.77 ; 1.64$ \\
\hline \multicolumn{13}{|l|}{ Nationality } \\
\hline Estonian/Latvian/Lithuanian & 1.00 & & 1.00 & & 1.00 & & 1.00 & & 1.00 & & 1.00 & \\
\hline Russian & 0.64 & $0.44 ; 0.95$ & 0.42 & $0.30 ; 0.58$ & 0.36 & $0.22 ; 0.60$ & 0.57 & $0.40 ; 0.81$ & 0.40 & $0.30 ; 0.54$ & 0.60 & $0.37 ; 0.98$ \\
\hline Other & 0.44 & $0.21 ; 0.92$ & 0.66 & $0.42 ; 1.04$ & 0.50 & $0.29 ; 0.86$ & 0.58 & $0.32 ; 1.05$ & 0.70 & $0.45 ; 1.07$ & 0.81 & $10.46 ; 1.43$ \\
\hline \multicolumn{13}{|l|}{ Area of residence } \\
\hline Urban & 1.00 & & 1.00 & & 1.00 & & 1.00 & & 1.00 & & 1.00 & \\
\hline Rural & 2.90 & $2.13 ; 3.95$ & 6.40 & $4.50 ; 9.10$ & 9.23 & $5.77 ; 14.76$ & 3.79 & $2.85 ; 5.03$ & 8.32 & $5.91 ; 11.70$ & 21.39 & $912.17 ; 37.60$ \\
\hline \multicolumn{13}{|c|}{ 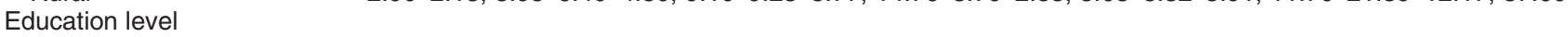 } \\
\hline Primary & 1.00 & & 1.00 & & 1.00 & & 1.00 & & 1.00 & & 1.00 & \\
\hline Secondary & 1.20 & $0.74 ; 1.94$ & 1.13 & $0.74 ; 1.73$ & 0.82 & $0.50 ; 1.34$ & 0.97 & $0.59 ; 1.61$ & 0.83 & $0.55 ; 1.25$ & 0.84 & $40.51 ; 1.38$ \\
\hline Secondary special/university & 1.26 & $0.76 ; 2.07$ & 1.45 & $0.96 ; 2.19$ & 0.90 & $0.57 ; 1.42$ & 1.01 & $0.60 ; 1.70$ & 1.38 & $0.93 ; 2.04$ & 1.21 & $10.77 ; 1.91$ \\
\hline \multicolumn{13}{|c|}{ Income level } \\
\hline Level 1 - low & 1.00 & & 1.00 & & 1.00 & & 1.00 & & 1.00 & & 1.00 & \\
\hline Level 2 & 0.63 & $0.42 ; 0.94$ & 0.69 & $0.49 ; 0.98$ & 0.89 & $0.60 ; 1.33$ & 1.13 & $0.81 ; 1.57$ & 0.73 & $0.54 ; 0.99$ & 0.90 & $0.63 ; 1.29$ \\
\hline Level 3 & 0.83 & $0.54 ; 1.27$ & 0.75 & $0.46 ; 1.21$ & 0.82 & $0.49 ; 1.38$ & 0.82 & $0.55 ; 1.24$ & 0.68 & $0.42 ; 1.10$ & 0.79 & $90.50 ; 1.25$ \\
\hline Level 4 - high & 0.58 & $0.33 ; 1.02$ & 0.33 & $0.18 ; 0.61$ & 0.89 & $0.58 ; 1.36$ & 0.68 & $0.34 ; 1.35$ & 0.64 & $0.34 ; 1.22$ & 0.74 & $40.50 ; 1.10$ \\
\hline
\end{tabular}

* OR - odds ratio; $\mathrm{Cl}$ - confidence interval. 
was 20-50 g greater among those living in rural areas than in urban areas. This may reflect the fact that the surveys were conducted during the summer, a period during which home-grown or purchased vegetables and fruits should be more easily accessible to those in rural areas. The overall values do, however, indicate the pressing need to find ways of improving the situation. Increased and local production and distribution of vegetables and fruits would not only help reduce food insecurity and improve the health of the population, but also stimulate local economic growth ${ }^{8}$.

In conclusion, the issue of food security in the Baltic States will need to be considered further as access to safe, healthy foods may help reduce diet-related morbidity and the high mortality rates from non-communicable diseases in these countries ${ }^{6}$.

Access to affordable, high-quality fresh foods by different social groups should be monitored and the potential contribution of home-grown and raised foods to reduce food poverty should be explored further.

\section{References}

1 World Health Organization (WHO). Definition of Food Security [Online]. Available at http://www.who.dk/nutriton/ food.htm. Copenhagen: WHO Regional Office for Europe, 2001.

2 Wilkinson RG. Unhealthy Societies; The Afflictions of Inequality. London: Routledge Publishers, 1996.

3 Fleming J, Mickleright J. Income Distribution, Economic Systems and Transition. Innocenti Occasional Papers, Economic and Social Policy Series, No. 70. Florence: United Nations Children's Fund-International Child Development Centre, 1999.

4 Food and Agriculture Organization (FAO). Food Insecurity: When People Must Live With Hunger and Fear Starvation. The State of Food Insecurity in the World 1999. Rome: FAO, 1999.
5 United Nations Children's Fund-International Child Development Centre (UNICEF-ICDC). TransMONEE Database 2000/EBRD. Florence: UNICEF-ICDC, 2000.

6 World Health Organization (WHO). Health for All Database. Copenhagen: WHO Regional Office for Europe, 2000.

7 Pudule I, Grinberga D, Kadziauskiene K, Abaravicius A, Vaask S, Robertson A, et al. Patterns of smoking in the Baltic Republics. J. Epidemiol. Community Health 1999; 53 277-82.

8 World Health Organization (WHO). Programme for Nutrition Policy, Infant Feeding and Food Security, ETC in the Netherlands, WHO Centre for Urban Health. Urban food and nutrition action plan (draft). Elements for local community action to promote local production for local consumption. Copenhagen: WHO Regional Office for Europe, October 1999

9 World Health Organization (WHO). Diet, Nutrition and the Prevention of Chronic Diseases. Report of a WHO study group. Technical Report Series No. 797. Geneva: WHO, 1990.

10 Pomerleau J, McKee M, Kadziauskiene K, Abaravicius A, Vaask S, Pudule I, et al. Macronutrient and food intake in the Baltic Republics. Eur. J. Clin. Nutr. 2001; 55: 200-7.

11 Wood D. European and American recommendations for coronary heart disease prevention. Eur. Heart J. 1998; 19(Suppl. A): A12-9.

12 World Cancer Research Fund/American Institute for Cancer Research (WCRF/AICR). Food, Nutrition and the Prevention of Cancer: A Global Perspective. Washington, DC: WCRF/AICR, 1997.

13 National Research Council. Premature Death in the New Independent States. Washington, DC: National Academy Press, 1997.

14 Rokx C, Galloway R, Brown L. Prospects for Improving the Nutrition Situation in Eastern Europe and Central Asia. New York: World Bank, 2000.

15 Robertson A. Food and Nutrition Assessment, Georgia. Copenhagen: WHO Regional Office for Europe, 1995.

16 Steckel RH. Industrialization and health in historical perspective. In: Leon D, Walt G, eds, Poverty, Inequality and Health: An International Perspective. Oxford: Oxford University Press, 2001. 